\section{Fatal course of foodborne botulism in an eight-month old infant}

\author{
Davide Lonati, ${ }^{1}$ Carlo Alessandro \\ Locatelli,1 Lucia Fenicia,2 \\ Fabrizio Anniballi,2 Paolo Landri, 3 \\ Andrea Giampreti, 1 Valeria Margherita \\ Petrolini, ${ }^{1}$ Sarah Vecchio, ${ }^{1}$ Luigi Manzo' \\ 1Pavia Poison Center and National \\ Toxicology Information Centre - \\ Toxicology Unit IRCCS Maugeri \\ Foundation and University of Pavia; \\ 2National Reference Centre for Botulism, \\ Department of Veterinary Public Health \\ and Food Safety, Istituto Superiore di \\ Sanità, Roma; 3 Intensive Care Unit, \\ S. Maria della Speranza Hospital, \\ Battipaglia, Italy
}

\section{Abstract}

An 8-month old girl, weighing $9 \mathrm{~kg}$, was brought by her parents at 8.15 am to the Emergency Department (ED) for a progressive worsening of weakness and acute respiratory failure. On admission, the baby presented with poor oral intake, a weak cry and extremely weak muscular body control. Poor gag and suck, unreactive mydriasis, hypotonia, lethargy and absence of peristalsis were noted. Laboratory data showed severe respiratory acidosis. Chest X-ray, electroencephalography, encephalic CT scan and MRI were all normal, as were cerebrospinal fluid analysis and viral tests. Orotracheal intubation and continuous mechanical ventilation were applied. The patient received fluids, corticosteroids, aerosol therapy, large-spectrum antibiotics and enteral-nutrition. Further investigation revealed ingestion of an improperly prepared homecanned homogenized turkey meal. Type A botulinum neurotoxin was identified. Trivalent botulinum antitoxin, prostigmine and oral activated charcoal were administered. Generalized flaccid paralysis, areflexic bilateral mydriasis, gastric stasis and deep coma persisted for the duration of the hospital stay, and the patient died of severe respiratory failure and cardiac arrest 12 days after ED admission. Botulism poisoning should be suspected in any infant presenting with feeding difficulties, constipation, descendent paralysis or acute respiratory failure. Supportive treatment and antidotal therapy should be performed as soon as a clinical diagnosis is made. We describe a case of foodborne botulism in an 8-month old infant caused by ingestion of an improperly prepared home-canned homogenized turkey meal, representing the youngest fatal case reported in medical literature.

\section{Introduction}

Botulism is a neuroparalytic disease caused by the blockade of neural transmission in the cholinergic synapses due to botulinum neurotoxins. These are mainly produced by the Clostridium botulinum or, rarely, by the neurotoxigenic Clostridium butyricum and Clostridium baratii. These neurotoxins can be distinguished in seven types (A-G). The human botulism is primarily related to types $\mathrm{A}$, $\mathrm{B}, \mathrm{E}$ and rarely to type $\mathrm{F}$. All forms of botulism (foodborne, wound, infant botulism, adult intestinal toxemia, inhalational and iatrogenic botulism) are characterized by the same clinical syndrome, including an acute/subacute afebrile condition and symmetric descending flaccid paralysis. ${ }^{1}$ Foodborne botulism is caused by ingestion of preformed toxin in food. The onset of clinical manifestations can be rapid and dramatic, differing from the infant form which usually develops less rapidly as the result of progressive intestinal colonization by neurotoxigenic clostridia and subsequent intraluminal production and absorption of toxin. ${ }^{2}$ We describe here a case of foodborne botulism in an 8-month old infant caused by ingestion of an improperly prepared homecanned homogenized turkey meal, representing what is to our knowledge the youngest fatal case reported in medical literature.

\section{Case Report}

An 8-month old girl, weighing $9 \mathrm{~kg}$, was brought by her parents at 8.15 am to the Emergency Department (ED) for a progressive worsening of weakness and dyspnea which had appeared two hours before. Medical history was negative for perinatal or delivery complications, and the baby was normal for development and growth; the mother had had no prenatal infections. Physical examination revealed a body temperature of $36.6^{\circ} \mathrm{C}$, oxygen saturation of $86 \%$ on room air, blood pressure of $90 / 40 \mathrm{mmHg}$, pulse rate of 160 beats/min and respiratory rate of 44 breaths/min. The patient's general appearance was lethargic with pallor, poor oral intake, weak cry and weak muscular body control. Pulmonary clinical evaluation showed bronchostenosis, diffuse wheezing and murmur reduction at the right lower lung field. Laboratory analysis revealed white blood cell count of $15.9 \times 109 / \mathrm{L}$ (27\% neutrophils and $62 \%$ lymphocytes). Serum sodium level was $128 \mathrm{mEq} / \mathrm{L}$, serum magnesium $1.7 \mathrm{mg} / \mathrm{dL}$, blood glucose 178
Correspondence: Davide Lonati,Pavia Poison Center and National Toxicology Information Centre - Toxicology Unit, IRCCS Maugeri Foundation and University of Pavia, via Salvatore Maugeri, 10 - 27100 Pavia, Italy. Tel: +39.0382 .26261 - Fax +39.0382 .24605 . E-mail: davide.lonati@fsm.it

Key words: poisoning, antidote, botulinum neurotoxins, infancy.

Contributions: DL patient management, data collection and article drafting; CAL drafting article; PL data collection and patient management; LF and FA laboratory analysis; AG, VMP and SV data collection and review; LM review.

Conflict of interest: the authors report no conflicts of interest.

The case described here has been presented as an abstract at the XXIX International Congress of the European Association of Poison Centres and Clinical Toxicologists (Stockholm, Sweden, May 12-15, 2009).

Received for publication: 8 August 2011. Accepted for publication: 13 October 2011.

This work is licensed under a Creative Commons Attribution NonCommercial 3.0 License (CC BYNC 3.0).

CCopyright D. Lonati et al., 2011

Licensee PAGEPress, Italy

Pediatric Reports 2011; 3:e31

doi:10.4081/pr.2011.e31

$\mathrm{mg} / \mathrm{dL}$ and lactate dehydrogenase $602 \mathrm{IU} / \mathrm{L}$. All other parameters were in the normal range including hemoglobin $(13.50 \mathrm{~g} / \mathrm{dL})$, hematocrit (40.7\%), potassium (3.5 mEq/L), chloride (97 $\mathrm{mE} q / \mathrm{L})$ and calcium $(9.9 \mathrm{mg} / \mathrm{dL})$. Initial arterial blood gases on room air showed a $\mathrm{pH}$ value of 6.89 , oxygen tension $36.4 \mathrm{mmHg}$, carbon dioxide tension $121 \mathrm{mmHg}$, bicarbonate 12.5 $\mathrm{mmoL} / \mathrm{L}$, lactate $2.2 \mathrm{mmoL} / \mathrm{L}$ and base excess of $-9.4 \mathrm{mmoL} / \mathrm{L}$ with oxygen saturation of $48.4 \%$. The patient was promptly intubated and treated with intravenous fluids $(500 \mathrm{~mL}$ of $5 \%$ dextrose solution and $8 \mathrm{ml}$ of $0.9 \%$ sodium chloride at a $30 \mathrm{ml} / \mathrm{h}$ infusion rate), hydrocortisone $80 \mathrm{mg}$ intramuscularly, methylprednisolone 8 $\mathrm{mg}$ intravenously associated with adrenaline $0.5 \mathrm{mg}$, and beclometasone $0.8 \mathrm{mg}$ by aerosol. Chest X-ray, EEG, cranial CT scan and MRI, as well as cerebrospinal analysis were all normal. Two hours after arrival in the ED the patient was transferred to the Paediatric Intensive Care Unit (PICU) of the nearest hospital where volume-cycled mechanical ventilation $\left(\mathrm{FiO}_{2}\right.$ 0.5, $\mathrm{PaO}_{2} / \mathrm{FiO} 2$ ratio 177.2) was started.

At PICU admission, the infant was minimally responsive, with some visual response to pain, poor cough and minimal gag. Pulmonary 
clinical evaluation showed expiratory whistles and diffuse moist rales in both lungs; thick corpuscular secretions were aspirated through the oro-tracheal tube and collected for cultural assays. During the first six hours in PICU the clinical picture worsened to a lethargic and diffusely hypotonic child with unreactive mydriasis, poor gag and suck, and absence of peristalsis and tendon reflexes.

Further investigation revealed that, the day before, the patient had ingested an improperly prepared home-canned homogenized turkey meal. Parents revealed that during the canning procedure, jars filled with turkey-meat had been boiled without a pressure cooker, stored at room temperature and not re-warmed before feeding. Foodborne botulism was suspected. Serum, food leftover samples (that appeared greenish and had a bad smell), rectal swabs and four unopened jars of food were immediately sent to the Italian National Reference Centre for Botulism at the National Institute of Health for laboratory analysis. Botulism poisoning was confirmed after ten hours. A mouse-bioassay testing of food leftovers was positive for type A toxin with 4000 Minimal Lethal Dose (MLD) per gram of food. C. botulinum type A was also detected by PCR assay and cultural method in both food leftovers and rectal swabs. On Day 2, electromyography showed low amplitude, short-duration, abundant motor-unit action potentials consistent with the described pattern of botulism poisoning. 3 During hospitalization, the patient received symptomatic treatment with fluids, enteral nutrition, methylprednisolone $10 \mathrm{mg}$ bid, ranitidine $25 \mathrm{mg} /$ day, $18 \%$ mannitol 10 $\mathrm{ml} /$ day, and large spectrum antibiotics (ceftazidime $250 \mathrm{mg}$ bid for the first two days and subsequently ceftriaxone $700 \mathrm{mg} /$ day). Fluconazole (400 mg/day) was started from
Day 4, paracetamol (250 mg bid) from Day 5 and albumin ( $10 \mathrm{~mL} /$ day) from Day 6 . Trivalent botulinum antitoxin was obtained from the Health Ministry stockpile and then administered intravenously $(250 \mathrm{~mL}, 25 \mathrm{~mL} / \mathrm{h}$ infusion rate) $10 \mathrm{~h}$ after laboratory confirmation of poisoning. Oral activated charcoal (5 $\mathrm{g}$ by nasogastric tube) and intravenous prostigmine ( $0.05 \mathrm{mg} / \mathrm{kg}$ bid) were also administered. Eight days after admission, an EEG revealed diffuse subcortical distress that worsened to a flat EEG during the following $24 \mathrm{~h}$. Generalized flaccid paralysis, areflexic bilateral mydriasis, gastric stasis of 20-40 mL/die and deep coma with GCS 3 persisted for the duration of hospital stay, and the patient died from severe respiratory failure and cardiac arrest 12 days after ED admission.

\section{Discussion}

Botulism in infancy is rare. The 'infant' form is reported the most frequently under one year of age.1,2,4 In one case of foodborne botulism described in the US, the patient (a six month-old infant) gradually recovered from a severe neuroparalytic picture after a 6-week period of intensive care. ${ }^{5}$ Foodborne cases have also been reported in 1 to 2 year-old infants ( 2 fatal and 3 non-fatal cases) mostly due to ingestion of home-canned baby food.5,6 In Italy, infant botulism has been the only form diagnosed in infants, with a total of 32 cases reported from 1984 to July 2011. Our case represents the first foodborne botulism involving an infant under the age of one year in Europe and the youngest fatal botulism case ever reported. The severe respiratory failure observed in this patient was consistent with ingestion of a large dose of type A toxin, the most potent type of botulinum neurotoxins. ${ }^{7}$ Laboratory confirmation was made by the official mouse-bioassay (intraperitoneal injections of white mice unprotected and protected with polyvalent botulinum antitoxin) and real time PCR, a valuable technique recently introduced to detect pathogenic micro-organisms in food, environmental and clinical samples.1,8 Based on the toxin level found in the food leftovers and the estimated consumption of about $50 \mathrm{~g}$ of contaminated food, the type A neurotoxin dose ingested by the patient was probably as high as 200,000 MLDs.

The antidote used in this patient $(250 \mathrm{~mL}$ Trivalent Equine Antitoxin, Behring) can induce passive immunization due to the neutralization of the circulating toxins. There are currently three different botulinum antitotoxin formulations available in Europe and the US (Table 1).1,9,10,11 The Trivalent Equine Antitoxin is indicated for all forms of botulism. Notably, the recommended dose of the European antidote is approximately 50 -fold higher compared to the US HBAT.

In fact, the appropriate dosage for the antitoxin formulations currently used in botulism is still a subject of debate. In particular, for the European antidote, there is no information available in literature, nor any guidance from the manufacturer on the management of botulism in infancy. Recently, the US FDA has licensed an intravenous human-derived immune-globulin preparation (BabyBIG) for infant botulism (Table 1). ${ }^{11}$ There is only one report describing the use of this product for treatment of foodborne disease in infancy. 5

Our patient received supportive therapy, gastrointestinal decontamination and antidotic treatment. Prostigmine was given to contrast the anticholinergic-induced ileus and

Table 1. Botulinum Antitoxin formulations available in Italy and in the US.

\begin{tabular}{|c|c|c|c|c|c|c|c|}
\hline $\begin{array}{l}\text { Botulinum } \\
\text { antitoxin }\end{array}$ & Formulation & $\begin{array}{l}\text { Antitoxin } \\
\text { types }\end{array}$ & $\begin{array}{l}\text { Concentration per vial/ } \\
\text { bottle (IU) }\end{array}$ & $\begin{array}{l}\text { Concentration } \\
\text { per mL (IU) }\end{array}$ & $\begin{array}{l}\text { Dosage and route } \\
\text { of administration }\end{array}$ & $\begin{array}{l}\text { Clinical } \\
\text { indication }\end{array}$ & Ref. \\
\hline $\begin{array}{l}\text { Trivalent equine } \\
\text { antitoxin }{ }^{\circledR} \text { (Behring) }\end{array}$ & $250 \mathrm{~mL} /$ bottle & $\begin{array}{l}\text { anti-A } \\
\text { anti-B } \\
\text { anti-E }\end{array}$ & $\begin{array}{c}187500 \\
125000 \\
12500\end{array}$ & $\begin{array}{c}750 \\
500 \\
50\end{array}$ & 2 bottles i.v. & All botulism forms & 1 \\
\hline $\begin{array}{l}\text { US HBAT investigational } \\
\text { heptavalent equine } \\
\text { antitoxin, } \\
\text { (Cangene Corporation) }\end{array}$ & $20 \mathrm{~mL} /$ vial & $\begin{array}{l}\text { anti-A } \\
\text { anti-B } \\
\text { anti-C } \\
\text { anti-D } \\
\text { anti-E } \\
\text { anti-F } \\
\text { anti-G }\end{array}$ & $\begin{array}{l}7500 \\
5500 \\
5000 \\
1000 \\
8500 \\
5000 \\
1000\end{array}$ & $\begin{array}{c}375 \\
275 \\
250 \\
50 \\
425 \\
250 \\
50\end{array}$ & 1 vial i.v. & $\begin{array}{l}\text { All botulism forms } \\
\text { except infant botulism } \\
\text { type A or B }\end{array}$ & $1,9,10$ \\
\hline $\begin{array}{l}\text { Botulism immune } \\
\text { globulin intravenous } \\
\text { (Human) (BIG-IV) } \\
\text { (Baby BIG }{ }^{\circledR} \text { ) } \\
\text { (Massachusetts public } \\
\text { health biologic } \\
\text { laboratories and cangene } \\
\text { corporation) }\end{array}$ & $\begin{array}{l}\text { Single-dose vial } \\
\text { containing } \\
100 \mathrm{mg} \pm 20 \mathrm{mg} \\
\text { of lyophilized } \\
\text { immunoglobulin }\end{array}$ & $\begin{array}{l}\text { anti-A } \\
\text { anti-B }\end{array}$ & & $\begin{array}{l}\text { At least } 15 \\
\text { At least } 2.0\end{array}$ & $\begin{array}{c}2.0 \mathrm{~mL} / \mathrm{kg} \\
(100 \mathrm{mg} / \mathrm{kg}) \text { i.v. }\end{array}$ & $\begin{array}{l}\text { Infant botulism } \\
\text { type A or B }\end{array}$ & 11 \\
\hline
\end{tabular}


facilitate removal of the contaminated food, spores and toxins from the gut.1,12 Based on the estimated amount of the toxin ingested, the administered dose of the antitoxin was likely high enough to neutralize the circulating poison. Despite precise patient history, prompt laboratory investigation and treatment, clinical evolution was progressively rapid and fatal.

Preventing food contamination remains the most relevant approach for botulism. People using home canning and food preservation processes should be educated about the correct time, pressure, and temperature required to destroy spores and botulinum toxins. Clinical manifestations of botulism in infancy may be difficult to recognize because of its insidious onset and the lack of a specific history. 13 The antidotic management of severe poisoning in infants has still not been clarified.

\section{References}

1. Lonati D, Rossetto 0, Fenicia L, Locatelli
C. Botulism. In: B Ballantyne, T Marrs, T Syversen (eds.) General and Applied Toxicology, 3rd ed. Chicester, UK, John Wiley and Sons Ltd, 2009, p 3555-79.

2. Fenicia L, Anniballi F. Infant botulism. Ann Ist Super Sanita 2009;45:134-46.

3. Cherington M. Clinical spectrum of botulism. Muscle Nerve 1998;21:701-10.

4. Koepke R, Sobel J, Arnon SS. Global occurrence of infant botulism, 1976-2006. Pediatrics 2008;122:e73-82.

5. Armada M, Love S, Barrett E, et al. Foodborne botulism in a six-month-old infant caused by home-canned baby food. Ann Emerg Med 2003;42:226-9.

6. Fischer D, Freislederer A, Jorch G. Sudden death of twins: botulism because of contamination by pap vegetables. Klin Padiatr 2004;216:31-5.

7. Woodruff BA, Griffin PM, McCroskey LM, , et al. Clinical and laboratory comparisons of botulism from toxin types A, B and E in the United States, 1975-1988. J Infect Dis 1992;166:1281-6.

8. Case definitions for infectious conditions under public health surveillance. Centers for Disease Control and Prevention. MMWR Recomm Rep 1997;46:1-55.

9. Dembek ZF, Smith LA, Rusnak JM. Botulism: cause, effects, diagnosis, clinical and laboratory identification, and treatment modalities. Disaster Med Public Health Prep 2007;1:122-34.

10. Centers for Disease Control and Prevention (CDC). Investigational heptavalent botulinum antitoxin (HBAT) to replace licensed botulinum antitoxin $\mathrm{AB}$ and investigational botulinum antitoxin E. MMWR Morb Mortal Wkly Rep 2010;59:299.

11. Arnon SS, Schechter R, Maslanka SE, et al. Human botulism immune globulin for the treatment of infant botulism. N Engl J Med 2006;354:462-71.

12. Isbister GK, Oakley P, Whyte I, Dawson A. Treatment of anticholinergic-induced ileus with neostigmine. Ann Emerg Med 2001;38:689-93.

13. Paerregaard A, Angen 0, Lisby M, et al. Denmark: botulism in an infant or infant botulism?. Euro Surveill 2008;13:19072. 